\title{
An Archaeological Survey of the Probst and McGriff Leases in Live Oak County, Texas
}

Ralph Snavely

Follow this and additional works at: https://scholarworks.sfasu.edu/ita

Part of the American Material Culture Commons, Archaeological Anthropology Commons, Environmental Studies Commons, Other American Studies Commons, Other Arts and Humanities Commons, Other History of Art, Architecture, and Archaeology Commons, and the United States History Commons

Tell us how this article helped you.

This Article is brought to you for free and open access by the Center for Regional Heritage Research at SFA ScholarWorks. It has been accepted for inclusion in Index of Texas Archaeology: Open Access Gray Literature from the Lone Star State by an authorized editor of SFA ScholarWorks. For more information, please contact cdsscholarworks@sfasu.edu. 


\section{An Archaeological Survey of the Probst and McGriff Leases in Live Oak County, Texas}

\section{Creative Commons License}

\section{(c) (1) \&}

This work is licensed under a Creative Commons Attribution-NonCommercial 4.0 International License 
AN ARCHAEOLOGICAL SURVEY OF THE

PROBST AND MCGRIFF LEASES IN

LIVE OAK COUNTY, TEXAS

Ralph Snavely

Center for Archaeological Research The University of Texas at San Antonio Archaeological Survey Report, No. 139 
A list of publications offered by the Center for Archaeological Research can be obtained by sending $\$ 1.00$ to the Center for Archaeological Research, The University of Texas at San Antonio, San Antonio, Texas 78285. 


\section{ABSTRACT}

During March 1984, an archaeological survey was carried out on the Probst and McGriff leases in Live 0ak County, Texas, for Chevron Resources Company. No cultural resources were found on the Probst lease. However, two prehistoric sites (41 LK 270 and 41 LK 271) were located on the McGriff lease. The two archaeological sites are described as lithic scatters which are eroded and otherwise disturbed by land modifications. The sites are not considered to be potentially significant cultural resources, and therefore not deemed eligible for nomination to the National Register of Historic Places. We recommend that no further work is needed. 


\section{TABLE OF CONTENTS}

ABSTRACT ..............................

LIST OF FIGURES . . . . . . . . . . . . . . . . . . . $i_{i}$

ACKNOWLEDGMENTS ............................ ... . . . . .

INTRODUCTION ................................... 1

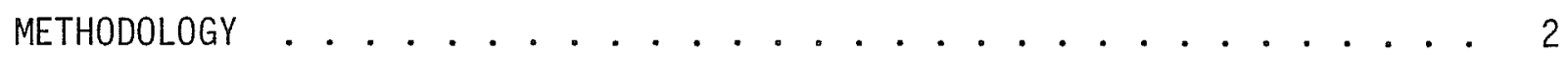

ARCHAEOLOGICAL BACKGROUND ..................... 2

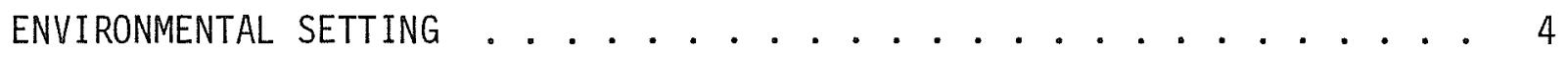

SURVEY RESULTS ......................... . . . 4

McGriff Lease . . . . . . . . . . . . . . . . 6

41 LK $270 \ldots \ldots . \ldots 6$

41 LK $271 \ldots \ldots . \ldots 6$

Probst Lease . . . . . . . . . . . . . . 6

SUMMARY AND RECOMMENDATIONS ................... 9

REFERENCES CITED ..................... 9

\section{LIST OF FIGURES}

1. Indicated are Locations of the Probst and McGriff Leases

in Live Oak County, Texas .............. . 2

2. The McGriff Lease on SuTphur Creek Indicating the Locations

of 41 LK 270 and 41 LK 271 . . . . . . . . . . . . . . 5

3. Lithic Artifacts from 41 LK 270 . . . . . . . . . . . . . 7

4. Selected Artifacts from 41 LK 270 and 41 LK 271 ......... . 8 


\section{ACKNOWLEDGMENTS}

The author thanks Mr. M. D. Manka, Chevron Resources Company, for his kind assistance in providing maps and other information essential to complete the field investigations. Many thanks are also due to the CAR office staff, particularly Sharon Quirk, editor, for all the aid in preparing this manuscript. 



\section{INTRODUCTION}

During March 21-26, 1984, personnel from the Center for Archaeological Research (CAR), The University of Texas at San Antonio (UTSA), carried out archaeological surveys on the Probst and McGriff leases in Live Oak County, Texas (Fig. 1). The purpose of the survey was to evaluate the archaeological and historical potential of these two properties. The research was conducted under a letter agreement between Chevron Resources Company (1etters dated February 14 and March 20, 1984, from M. D. Manka) and the Center for Archaeological Research.

The field survey was conducted by Thomas C. Kelly, Research Associate, and Ralph Snavely, Technical Staff Assistant. Project supervision was provided by Principal Investigator Dr. Thomas R. Hester, Center Director, and Co-Principal Investigator Jack Eaton, Associate Director. The archaeological field studies reported herein comply with requirements for cultural resource assessment of lands to be subjected to surface mining under permit application to the Texas Railroad Commission ("Phase 2 intensive survey" as outlined in the Guidelines for Archeological Investigation of Mining Areas in Texas [Texas Historical Commission 1981]).

\section{METHODOLOGY}

Two separate areas were surveyed during field investigations, the Probst lease (ca. 300 acres) and the McGriff lease (ca. 250 acres). The following methods were followed in order to maximize data retrieval.

Each survey area was specifically identified on USGS 1:24,000 scale topographic maps. The surveys consisted of a series of pedestrian transects (ca. $25 \mathrm{~m}$ ). The study areas were divided into quadrants determined by distinct topographical features and then transected individually. Often these quadrants represented specific soil and vegetational occurrences bounded by man-made and natural land features.

Archaeological sites were plotted on USGS topographic maps in the field. Standard site survey forms used by the Center for Archaeological Research were used to record elevations, soil types, area vegetation, site distance to a water source, and other specific site information. Collected cultural remains were placed in bags and labeled as to site number, date, type of collection, name of collector, and other pertinent site information. Black and white photographs, a photograph log, all records, and collected artifacts are curated at the Center for Archaeological Research laboratory. Copies of site record forms are on file with the Texas Archeological Research Laboratory (TARL) in Austin.

\section{ARCHAEOLOGICAL BACKGROUND}

The types of prehistoric sites identified from previous archaeological research in Live Oak County include Targe campsites, smal1 temporary campsites, buried middens, lithic workshops, quarry sites, and prehistoric cemeteries. Hall, BTack, and Graves (1982), Prewitt and Scott (1977), and Hester (1980) provide 


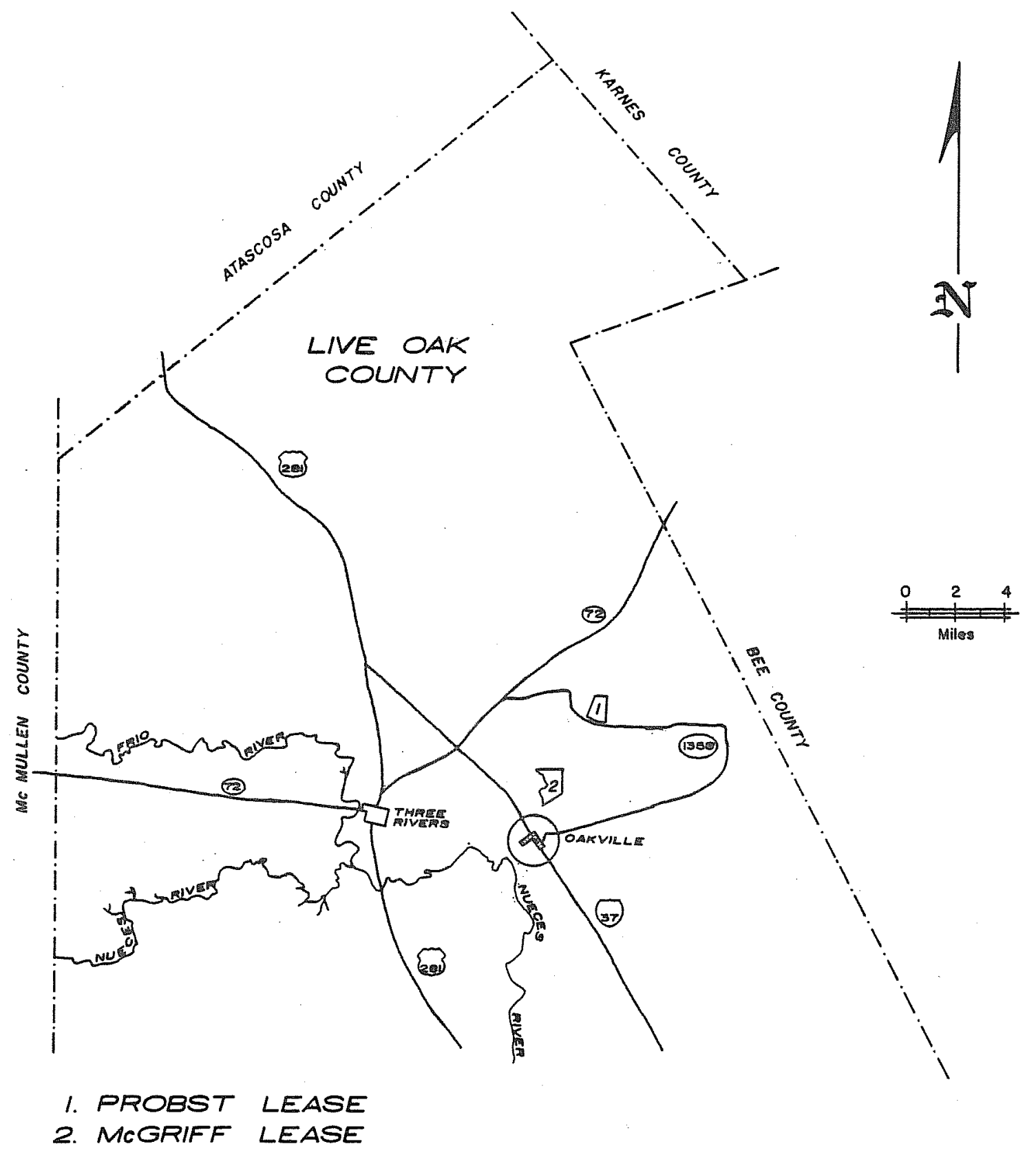

Figure 1. Indicated are Locations of the Probst and McGriff Leases in Live Oak county, Texas. 
detailed site descriptions. The four major time periods recognized in the Live Oak County area are: the Paleo-Indian (10,000 B.C. to 6000 B.C.), the Archaic (6000 B.C. to A.D. 1000), the Late Prehistoric (A.D. 1000 to A.D. 1600), and the Historic (after 1600). Within each of these periods archaeologists can detect changes in environmental conditions, subsistence activities, and distinctive tool assemblages.

Over 265 archaeological sites have been recorded in Live Oak County. Studies conducted by the CAR-UTSA in the Choke Canyon Reservoir area have added significantly to the archaeological record with over 400 archaeological sites recorded in the reservoir area, which includes both Live Oak and McMullen Counties (Hall, Black, and Graves 1982).

In 1975, the Texas Archeological Survey, The University of Texas at Austin, recorded 16 prehistoric and three historic sites in the Three Rivers Flood Protection Project (Mallouf 1975; Prewitt and Scott 1977; Dibble 1979; Pliska 1980). Also just north of Three Rivers, Texas, the Texas Department of Highways and Public Transportation excavated a cemetery site (41 LK 28) on the Atascosa River floodplain (see Hester 1980:82). This site contained more than 160 prehistoric burials, and produced artifacts from the Paleo-Indian, Archaic, and the Late Prehistoric periods.

During an archaeological survey conducted by the CAR-UTSA in 1977, site 41 LK 106 was recorded in northwest Live Oak County by Kelly and Hester (1977). The site located along Sulphur Creek was thought to represent a series of short-term occupations during the Middle to Late Archaic and Late Prehistoric periods. Subsequent excavations at 41 LK 106 in 1979 supported the evidence (Creel et al. 1979).

Other archaeological surveys in Live Oak County include the Conquista Project where two small prehistoric sites were recorded (McGraw 1979), and a survey in the northwest portion of the county where three small prehistoric sites were recorded (Robinson 1983).

Another site of particular importance, in that it is located directly adjacent to the Probst lease is 41 LK 117, tested and recorded by Smith (1978). This site was reported to extend over an area $1000 \mathrm{~m}$ by $3000 \mathrm{~m}$ in size and encompasses the largest surface area $\left(3,000,000 \mathrm{~m}^{2}\right)$ of any site recorded in Live 0ak County (TARL files). It was described by Smith (1978:5) as consisting "of a medium to 1 ight 1 ithic scatter with greater concentrations in some areas." All artifacts were collected from the surface. Shovel tests of the area revealed cultural material in only the top $10 \mathrm{~cm}$, with most shovel tests producing negative results. Within the entire site area, 120 chipped 1 ithics, one ground stone artifact, and seven ceramic sherds were collected from the surface (Smith 1978).

In addition to the research cited above, other published information documents various artifact types and sites in south Texas (Hester 1980; Ha11, Black, and Graves 1982). 


\section{ENVIRONMENTAL SETTING}

The Probst and McGriff survey areas are located approximately $11.2 \mathrm{~km}$ east of Three Rivers, Texas. The two areas are approximately $2 \mathrm{~km}$ apart, each adjacent to the east bank of Sulphur Creek. The topography, soils, natural vegetation, and general character of both properties are similar.

The flora and fauna of the surveyed areas are encompassed within the Tamaulipan Biotic Province as defined by Blair (1950). The flora of the area is a mesquite and desert grass savannah with uplands dominated by thorn brush and mesquite, native grasses, and prickly pear, while drainages are often dominated by thorn brush and mesquite. Riparian zones are often composed of elm, hackberry, pecan, ash, oak, and lush grasses (Blair 1950).

The fauna of the area includes white-tailed deer, coyote, fox, armadillo, javelina, squirrel, dove, wild turkey, quail, cottontail rabbit, jackrabbit, raccoon, and a variety of reptiles and fish (Lynn, Fox, and O'Ma11ey 1977;

Blair 1950:102).

The topography is that of gently rolling hills. Erosional cuts, some quite deep, extend from Sulphur creek inland to the second or third terrace. Sheet erosion is typical of the upland areas. The floodplain of Sulphur Creek consists of deep alluvial soil deposited in a series of sloughs paralleling the creek. The sloughs are capable of retaining a limited amount of water after heavy rains or flooding. Sulphur creek is a more permanent water source, depleted only under extremely dry conditions.

Geologically, the survey areas lie on the Catahoula Formation. The formation consists of tuffaceous clays, tuff, sandstone, conglomerate beds of chert, chalcedony, opal, and quartzite. Silicified wood, quartzite, and gravels of chert can be found within the Uvalde Gravels which are predominant in the stream bed of Sulphur Creek (Barnes 1976).

Upland areas of the McGriff lease have been heavily modified by agricultural activities. The agricultural modifications are evident over at least $75 \%$ of the property. Approximately $25 \%$ of the Probst lease ground surface was modified by a series of bulldozed vegetation breaks in a crosshatching manner across the upland areas.

\section{SURVEY RESULTS}

During the McGriff lease survey two archaeological sites were recorded (Fig. 2). These sites are near one another and may possibly represent one site, although no direct evidence could be found to actually link the two sites. The Probst lease revealed no significant cultural resources.

Each recorded site has been assigned permanent site number designations following the Smithsonian Trinomial system. The first two numbers indicate the state (41=Texas), followed by two letters that indicate the county (LK=Live $0 \mathrm{ak})$, and then numbers that indicate the site sequence within the county. 
This page has been

redacted because it

contains restricted

information. 


\section{McGriff Lease}

41 LK 270

Site 41 LK 270 is located at the approximate center of the McGriff survey area, on a bluff which overlooks alluvial terraces and Sulphur Creek. There are plowed fields to the northeast and southwest of the site. This site is approximately $30 \mathrm{~m}$ long and is scattered $20 \mathrm{~m}$ down along the side of the bluff, possibly a result of erosion. The site is on the west side of the bluff with a $180^{\circ}$ view. The elevation of 41 LK 270 ranges from 56.9 to $51.8 \mathrm{~m}$ above mean sea level.

A surface collection resulted in the recovery of 61 specimens of lithic debitage, four cores, a fragment of a hammerstone, six Clear Fork gouges (three are illustrated in Fig. $3, a, b, d)$, one unifacial gouge (Fig. 3,c), and 16 biface fragments (only one of these was illustrated; Fig. 4,b). Small burned hearth stones were also observed on the surface. Raw materials commonly used for artifacts in this area include chert, silicified wood, and chalcedony. All of these materials can be obtained from the Uvalde Gravel deposits associated with Sulphur Creek, approximately $300 \mathrm{~m}$ west of the site.

Site 41 LK 270 is best described as a lithic scatter. The condition of the site is poor due to excessive erosion and agricultural land modifications. Therefore, no further work is recommended.

\section{LK 271}

Site $41 \mathrm{LK} 271$ is located on the same bluff, ca. $120 \mathrm{~m}$ to the north, as 41 LK 270, and just above the floodplain ca. $250 \mathrm{~m}$ east of Sulphur Creek (Fig. 2). The shape of the site is oval, ca. $5 \mathrm{~m}$ by $8 \mathrm{~m}$ in area, and $4.8 \mathrm{~m}$ above mean sea level. A bulldozed path transects the north edge of the site, exposing a small amount of cultural material.

Artifacts from this site consist of lithic debitage and a Scallorn arrow point (Fig. 4,a). The Scallorn type is common in the Late Prehistoric period in south Texas (Hester 1980:102). No other cultural materials were observed at this site.

Site 41 LK 271 is described as a light lithic scatter. The present condition of this site is poor due to excessive erosion, road disturbance, and recent bul1dozer activity. No further work is recommended at 41 LK 271.

\section{Probst Lease}

The Probst lease survey failed to reveal any significant evidence of prehistoric or historic activity. Small and very widely scattered amounts of lithic debris did occur within the survey area, although no lithic debris concentrations or diagnostic artifacts were noted. 

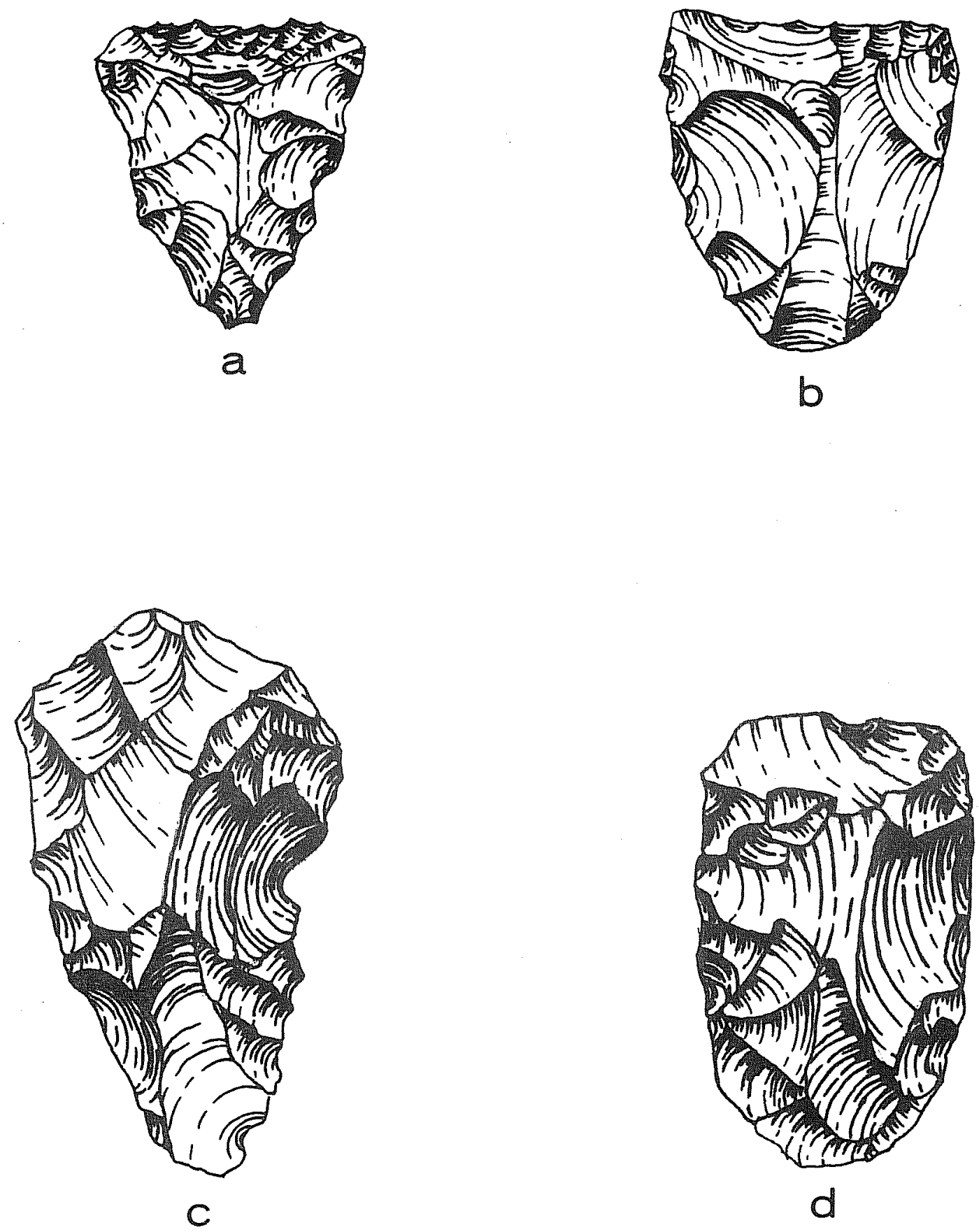

Figure 3. Lithic Artifiacts from 41 LK 270. a,b,d, Clear Fork gouges; $c$, unifacial gouge. 
8
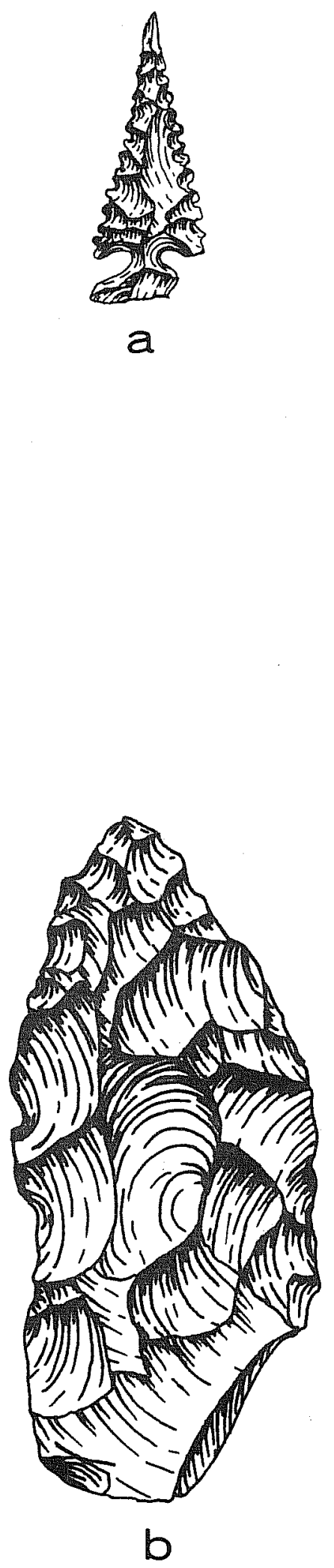

Figure 4. Selected Artifacts from 41 LX 270 and 41 LK 271. a, Scallorn arrow point, 41 LM 271 ; b, thin biface, 41 LI 270. 


\section{SUMMARY AND RECOMMENDATIONS}

A pedestrian survey was made of the Probst and McGriff Teases in Live Oak County. Two prehistoric sites were located and recorded during the course of this survey. Both sites are situated near each other on the McGriff lease. Site 41 LK 271 is located on the edge of the floodplain and is a lithic scatter. Site 41 LK 270 is located on the west side of a bluff and is also a lithic scatter. One diagnostic artifact, a Scallorn point, was found at site 41 LK 271. This type of artifact is associated with the Late Prehistoric period after A.D. 100 in south Texas (Hester 1980:105).

Because of the extent of erosion and the disturbances at both 41 LK 270 and 41 LK 271, and the lack of any potentially significant cultural deposits, these sites are not considered eligible for nomination to the National Register of Historic Places. No further work is recommended.

\section{REFERENCES CITED}

Barnes, V. E. (Project Director)

1976 Geologic Atlas of Texas. Crystal City-Eagle Pass Sheet. Bureau of Economic Geology, The University of Texas at Austin.

Blair, W. F.

1950 The Biotic Provinces of Texas. The Texas Journal of Science 2(1):93-117.

Cree1, D., A. J. McGraw, F. Valdez, Jr., and T. C. Kelly

1979 Excavations at 41 LK 106, a Prehistoric 0ccupation Site in Live Oak County, Texas. Center for Archaeological Research, The University of Texas at San Antonio, Archaeological Survey Report 62.

Dibble, D. S.

1979 Archeological Assessments at The Three Rivers Flood Protection Project. Texas Archeological Survey, The University of Texas at Austin, Technical Bulletin 26.

Ha11, G. D., S. L. Black, and C. Graves

1982 Archaeological Investigations at Choke Canyon Reservoir, South Texas: The Phase I Findings. Center for Archaeological Research, The University of Texas at San Antonio, Choke Canyon Series 5.

Hester, T. R.

1980 Digging Into South Texas Prehistory. Corona Publishing Company, San Antonio, Texas. 
Kelly, T. C. and T. R. Hester

1977 Archaeological Assessment of Cultural Resources on the FelderMcLean Leases, Live Oak County, Texas. Report submitted to Exxon Minerals Company, USA, by the Center for Archaeological Research, The University of Texas at San Antonio.

Lynn, W., D. Fox, and N. O'Malley

1977 Cultural Resource Survey of Choke Canyon Reservoir, Live Oak and McMullen Counties, Texas. Texas Historical Commission, Archeological Survey Report 20.

Mallouf, M. G.

1975 Three Rivers Flood Protection Project, Live Oak County, Texas: An Archeological and Historical Survey of Areas Proposed for Modification. Report submitted to the Fort Worth District, Corps of Engineers by the Texas Archeological Survey, The University of Texas at Austin.

McGraw, A. J.

1979 An Archaeological and Historical Survey of the Haase, Moy and Wiatrek Properties of the Conquista Project, Karnes County, Texas. Center for Archaeological Research. The University of Texas at San Antonio, Archaeological Survey Report 81.

Pliska, J. R.

1980 Archeological Investigations at the Three Rivers Flood Control Project: A Final Report. Texas Archeological Survey, The University of Texas at Austin, Technical Bulletin 30.

Prewitt, E. R. and R. J. Scott IV

1977 Three Rivers Floodwater Diversion Levee Project: Assessments at Archeological Sites 41 LK 57, 41 LK 113 and 41 LK 114. Report submitted to the Fort Worth District, Corps of Engineers by the Texas Archeological Survey, The University of Texas at Austin.

Robinson, D. G.

1983 A Cultural Resource Survey of the Chem Nuclear Systems Inc., Live Oak County Lease, Live Oak County, Texas. Texas Archeological Survey, The University of Texas at Austin, Technical Bulletin 73 . 
Smith, H. P., Jr.

1978 Archaeological Survey and Assessment of Properties for the Conquista Project in Live Oak and Karnes Counties, Texas. Center for Archaeological Research. The University of Texas at San Antonio, Archaeological Survey Report 64.

Texas Historical Commission

1981 Guidelines for Archeological Investigations of Mining Areas in Texas. Office of the State Archeologist, Texas Historical Commission, Austin. 
$\because$

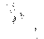


